\title{
PENGEMBANGAN JIWA BIOENTREPRENEUR MAHASISWA BIOLOGI
}

\author{
Roni Afriadi; (roniafriadi15@gmail.com) \\ Revita Yuni² ; (revitayuni25@gmail.com) \\ 2Universitas Negeri Medan
}

\begin{abstract}
ABSTRAK
Minat rendah dalam aktivitas wirausaha masyarakat Indonesia adalah salah satu penyebab tingginya pengangguran. Karena sebagian besar lulusan Universitas lebih dominan sebagai pencari kerja daripada menciptakan pekerjaan. Untuk alasan ini, kebutuhan untuk membentuk semangat kewirausahaan mahasiswa, untuk mengubah pola pikir mereka, sehingga setelah menjadi lulusan mereka telah merencanakan untuk membentuk bisnis atau menciptakan pekerjaan mereka sendiri. Kewirausahaan adalah inovator dan individu yang mengembangkan sesuatu yang unik dan baru. Biologi adalah ilmu alam yang mempelajari tentang organisme hidup dan interaksinya dengan lingkungan. Biologi adalah ilmu yang mempelajari begitu luas sehingga cabang-cabang biologi dibentuk untuk membuatnya mudah dipelajari. Dimana setiap cabang biologi memiliki karakteristik untuk dikembangkan sebagai peluang bisnis bagi mahasiswa biologi dan pendidikan biologi. Peluang bisnis ini dapat dikembangkan sesuai dengan minat dan kreativitas mahasiswa dan juga sesuai dengan zaman.
\end{abstract}

Kata Kunci: Kewirausahaan, Mahasiswa

\begin{abstract}
The low interest in entrepreneurial activity of the Indonesian people is one of the causes of high unemployment. Because most university graduates are more dominant as job seekers than creating jobs. For this reason, the need to shape the entrepreneurial spirit of students, in order to change their mindset, so that after becoming a graduate they have planned to form a business or create their own jobs. Entrepreneurship is an innovator and individual who is developing something unique and new. Biology is a natural science that studies about living organisms and their interactions with the environment. Biology is a science that studies so broadly that branches of biology were formed to make it easy to learn. Where each branch of biology has characteristics to be developed as a business opportunity for biology students and biology education. These business opportunities can be developed in accordance with the interests and creativity of students and also in accordance with the times.
\end{abstract}

Keywords: Entrepreneurship, Student

\section{PENDAHULUAN}

Pesatnya perkembangan ilmu pengetahuan dan teknologi menuntut kita harus mampu beradaptasi pada kehidupan sosial dan ekonomi masyarakat. Dimana seorang konsumen bisa mendapatkan barang yang diinginkan tanpa harus berhadapan dengan produsen atau distributor. Melainkan transaksi dapat dilakukan dengan cara online pada aplikiasi kusus (dibantu oleh biro pengiriman barang) maupun ojek online (dibantu oleh driver-nya masing-masing). Namun di Indonesia umumnya masih belum mampu beradaptasi dengan perubahan dan perkembangan tersebut. Hal ini dapat dibuktikan dengan tingginya tingkat pengangguran diantaranya adalah berprediket sarjana. Efek dari pengangguran tersebut berdampak terhadap pertumbuhan ekonomi nasional. Hal ini menunjukan bahwa, seorang sarjana tidak bisa mengandalkan kemampuan akademik (hard skill) saja, melainkan juga harus mempunyai kemampuan soft skills. Salah satu kemampuan soft skills yang wajib dimiliki oleh seorang sarjana adalah jiwa entrepreneurship.

Menurut pengamat, aktivitas kewirausahaan (entrepreneurship activity) masyarakat Indonesia relative rendah. Entrepreneurship activity diterjemahkan sebagai aktif dalam memulai bisnis baru dan dinyatakan dalam persen total penduduk aktif bekerja. Semakin rendah indek entrepreneurship activity suatu Negara berdampak terhadap tingginya angka pengangguran (Siswono: 2009). Berdasarkan data survei, tingginya angka pengangguran terdapat pada lulusan sarjana perguruan tinggi. Data pengangguran terdidik tersebut menyatakan bahwa semakin tinggi 
JURNAL BIOLOKUS Vol.1 (2)

pendidikan seseorang, semakin rendah kemandirian dan semangat kewirausahaanya. Karena sebagian besar lulusan Perguruan tinggi adalah lebih dominan sebagai pencari kerja (job seeker) dari pada menciptakan lapangan kerja (job creator). Hal ini disebabkan karena sistem pembelajaran diberbagai perguruan tinggi umumnya masih terfokus pada ketepatan lulus dan kecepatan memperoleh pekerjaan. Akibatnya minimnya penghasil kesiapan menciptakan lapangan kerja (entrepreneurship).

Entrepreneurship dalam bahasa Indonesia diartikan sebagai kegiatan kewirausahaan. Usaha yang dikelola dengan sikap manejerial sang pemilik gagasan atau ide. Jiwa wirausaha dalam diri seseorang ditandai dengan adanya komitmen pribadi untuk dapat mandiri, mencapai suatu yang diinginkan, menghindari ketergantungan pada orang lain agar lebih produktif mengembangkan potensi diri. Jiwa entrepreneurship dapat dibentuk mulai dari lingkungan keluarga, dan akademik. Lingkungan keluarga seperti, orang tua memotivasi anaknya melakukan hal kecil yang dapat mendukung kegiatan yang bersifat wirausaha. Sedangkan lingkungan pendidikan merupakan wadah mendapatkan ilmu dan tempat menerapkan ilmu guna melatih jiwa entrepreneurshipnya.

Jiwa entrepreneurship mahasiswa dibentuk guna mengubah pola pikir mahasiswa, agar setelah menjadi sarjana nanti mereka sudah merencanakan membentuk usaha atau menciptakan lapangan kerja sendiri dan bukan terfokus pada pencari kerja. Untuk itu mahasiswa perlu dibekali secara teoritis tentang peluang usaha yang dapat dikembangkan berdasarkan potensi lokal maupun nasional. Selain itu juga dengan cara praktek seperti study lapangan ke beberapa perusahaan atau home industry. Dengan harapan mahasiswa dapat melihat secara langsung dan berbagi pengalaman dengan pengusaha dalam menjalankan usahanya. Selain itu, didukung oleh kegiatan kemahasiswaan yang diselenggarakan oleh Program Kreativitas Mahasiswa bertujuan untuk pembinaan sikap kewirausahaan seperti kegiatan Bazar kreativitas mahasiswa. Dalam kegiatan bazar menampilkan produk-produk hasil kreativitas mahasiswa.

Sebagai mahasiswa generasi muda harus berani melangkah mengambil keputusan terhadap persaingan global. Persaingan akan mendorong menjadi pengusaha yang lebih kreatif dan inovatif dalam mengembangkan usaha. Seorang pengusaha harus memiliki perencanaan yang matang, tujuan yang jelas, action sepenuh hati, tidak ada rasa malu (karena bertindak diatas kebenaran) dan tidak takut rugi.

Menurut Ciputra menyatakan seorang entrepreneur sudah pasti seorang pengusaha, sedangkan seorang pengusaha belum tentu dapat dikatakan entrepreneur. Ciri-ciri seorang entrepreneur diantaranya, ia merasakan peluang dan mengejar peluang yang ia rasa cocok dengan dirinya serta percaya bahwa keberhasilan pasti dapat dicapai.

Seorang entrepreneur tidak mudah menyerah karena mereka yakin akan berhasil dengan bidang yang mereka pilih. Seorang entrepreneur juga merupakan orang yang bertindak melakukan inovasi serta berani mengambil risiko, baik risiko mental maupun risiko finansial. Seorang pengusaha belum tentu seorang entrepreneur karena bisa jadi ia meniru ide usaha yang sudah ada sehingga tidak melakukan inovasi, atau ia mendapat usaha yang sudah dibangun oleh keluarganya sehingga tidak memulai bisnis dengan visi yang berasal dari dirinya.

\section{Kewirausahaan (Entrepreneurship)}

Istilah kewirausahaan (entrepreneur) pertama kali diperkenalkan oleh ekonom prancis yaitu Ricard Cantilon (1755) yang menyatakan "Entreprenueral is innovator and individual developing samoting unique and new" artinya kewirausahaan adalah inovator dan individu yang sedang mengembangkan sesuatu yang unik dan baru (Dewi, 7 : 2016). Selain itu La Hatani (2008) menyatakan kewirausahaan adalah kemampuan diri seseorang untuk menentukan dan mengevaluasi peluang-peluang usaha dengan mengelola sumber daya yang ada. Oleh karena itu, kewirausahaan yang melekat pada diri manusia, sementara keberadaan manusia didunia merupakan makhluk utama dan titik sentral berkembangnya peradaban masyarakat. Sehubungan dengan hal tersebut terdapat 4 elemen pokok yang perlu disadari akan eksistensi keberadaan manusia dalam memahami falsafah/ hakekat wirausaha yaitu sebagai berikut :

1. Hakekat keberadaan manusia adalah pekerja dan tanpa bekerja fungsi manusia dipermukaan bumi akan kehilangan makna, 
JURNAL BIOLOKUS Vol.1 (2)

dengan demikian bekerja adalah indikator eksistensi manusia.

2. Kewajiban manusia dalam hidup, manusia dalam hidup wajib bekerja artinya bekerja disini agar kehidupan yang lebih beradap karena manusia bekerja untuk mempertahankan hidup atau kebelangsungan hidupnya. Dengan bekerja hidup lebih bergairah, dinamis dan menyenangkan sehingga keberadaan diri manusia menjadi lebih bernilai.

3. Etos kerja, merupakan salah satu inner dynamic factor (faktir dinamika yang berada dalam diri manusia). Bekerja berarti menghasilkan sesuatu baik secara kuantitatif maupun secara kualitatif. Dalam hal ini terdapat dua variable yang saling berhubungan yaitu manfaat/ kegunaan dan produktivitas.

4. Kebutuhan hidup, manusia bekerja guna memenuhi kebutuhan hidup dan keberlangsungan hidupnya. Dari perjalanan tahapan kehidupan manusia, kebutuhan manusia selalu mengalami proses perkembangan dan sangat beragam.

Menurut (Sagoro. $1: 2013$ ) Kewirausahaan (entrepreneurship) adalah proses menciptakan nilai dengan mengumpulkan beberapa sumber daya manusia yang bersifat unik oleh seseorang untuk digunakan sebagai modal untuk mengambil kesempatan bisnis yang ada atau kemampuan seseorang untuk menghasilkan barang dan jasa dengan kreativitasnya bertujuan mencari keuntungan. Dengan kata lain wirausahawan (entrepreneur) adalah mereka yang selalu mencari perubahan, berusaha mengikuti dan menyesuaikan perubahan itu, mampu mengambil peluang, serta berani mengambil resiko dalam setiap peluang yang di ambil. Wirausahawan selalu mampu berinovasi (innovative) dengan berbagi kreativitasnya untuk menghasilkan sesuatu yang dibutuhkan masyarakat. Ciri-ciri wirausahawan yang inovatif menurut Harjono (2012) adalah sebagai berikut: 1) Berfikir dan bertindak strategis serta adaptif terhadap perubahan dalam berusaha mencari peluang keuntungan termasuk yang mengandung resiko yang besar dan cara mengatasi masalah; 2) Selalu berusaha mendapatkan keuntungan melalui berbagai keunggulan dalam memuaskan pelanggan; 3) Berusaha mengenal dan mengendalikan kekuatan dan kelemahan perusahaan serta meningkatkan kemampuan system dengan pengendalian; 4) Selalu berusaha meningkatkan kemampuan dan ketangguhan terutama dengan pembinaan motivasi dan semangat kerja serta menumpukan permodalan.

Beberapa manfaat kewirausaan diantaranya adalah sebagai berikut : 1) Membuka lapangan kerja baru; 2) Sebagai generator pembangunan lingkungan; 3) Sebagai contoh pribadi unggul, terpuji, jujur, berani, dan tidak merugikan orang lain; 4) Menghormati hukum dan peraturan yang berlaku; 5) Mendidik karyawan jadi mandiri, disiplin, jujur, dan tekun; 6) memlihara keserasian lingkungan baik dalam pergaulan maupun dalam kepemimpinan (Anonimous: kewirausahaan)

\section{Membentuk sikap Bioentrepreneurship Mahasiswa Biologi}

Sikap membuat seseorang berada dalam suatu kerangka berfikir yang lebih baik dan menentukan seseorang untuk berprilaku relative konsisten. Menurut Fishbein dan Ajzen dalam Purwanto (2006) menyatakan bahwa sikap merupakan predisposisi yang dipelajari untuk menaggapi secara konsisten terhadap suatu objek baik bentuk tanggapan positif maupun negatif. Sikap merupakan keadaan yang mudah terpengaruh dan sikap juga dapat dibentuk melalui pembiasaan dan pendidikan. Sedangkan minat seseorang terhadap aktivitas merupakan salah satu faktor yang menentukan pilihan terhadap aktivitas tersebut.

Karakteristik yang khas dari kelompok usaha adalah menyangkut bakat (personality traits). Membentuk seorang wirausahawan memulai usaha dan bagaiman mereka bertahan dalam kondisi lingkungan yang berubah (open-ended change). Keberhasilan usaha sering berkaitan dengan bakat yang dimiliki pengusaha (Hatani; 2008). Namun pendapat lain menyatakan bahwa untuk menjadi wirausahawan tidaklah hanya cukup bakat (dilahirkan) tapi dibentuk melalui pendidikan, pelatihan atau bergaul dalam lingkungan komunitas dunia usaha. Oleh karena itu, untuk belajar berwirausaha tidak hanya mengandalkan bakat, namum yang lebih penting adalah memiliki kemauan dan motivasi yang kuat untuk memulai usaha.

Motivasi menjadi seorang pengusaha yang bermanfaat bagi diri sendiri, keluarga dan masyarakat melalui pencapain prestasi kerja. 
JURNAL BIOLOKUS Vol.1 (2)

Manfaat sebagai seorang wirausahawan dapat diuraikan sebagai berikut:

a. Memiliki kebebasan mengaktualisasikan potensi yang dimiliki. Umumnya wirausahawan berhasil berhasil mengelola usahanya karena keterampilan/ hobinya menjadi pekerjaan. Artinya bekerja dengan rasa iklhas tanpa terbebani. Berwirausaha menjadikan kita terbebas menentukan nasib dan mengontrol sendiri keuntungan yang ingin dicapai dengan tanpa batas.

b. Memiliki peluang untuk berperan bagi masyarakat. Wirausahawan menciptakan produk (barang atau jasa) yang dibutuhkan oleh masyarakat. Pemberian pelayanan pada masyarakat terutama konsumen yang dilandasi tanggungjawab sosial melalui penciptaan produk yang berkualitas (Rukka, 2011).

Selain itu karakteristik yang harus dimiliki oleh wirausahawan menurut Sagoro (3:2013) adalah: 1) Selalu berfikir positif, merupakan sikap mental yang melibatkan proses memasukan pikiran-pikiran atau gambaran positif yang dapat membangun perkembangan pikiran, optimis, semangat mencapai kesuksesan; 2) Bekerja keras dan cerdas adalah usaha yang dilakukan wirausahawan serta focus dan optimal, memanfaatkan waktu dan energi yang dimiliki dengan semangat tinggi untuk memenuhi berbagi kebutuhan; 3) Disiplin, merupakan ketepatan komitmen wirausahawan terhadap tugas dan pekerjaan. Baik terhadap waktu, kualitas pekerjaan sesuai dengan standar yang telah ditetapkan; 4) Komitmen tinggi terhadap kemajuan usaha. Komitmen merupakan kesepakatan mengenai sesuatu hal yang dibuat baik terhadap diri maupun orang lain yang berorientasi terhadap kemajuan usaha; 5) Mandiri mengelola sendiri tanpa ketergantungan dari pihak lain dalam bertindak dan mengambil keputusan; 6) Kreatif dan inovatif agar mampu bertahan. Karena untuk dapat bersaing, maka wirausahawan harus memiliki daya kreatif yang dilandasi oleh cara berpikir maju.

Sikap hal tersebut hendaknya dimiliki oleh seorang mahasiswa Biologi dan Pendidikan Biologi disetiap perguruan tinggi. Karakter kewirausahaan dapat diimplemetasikan disetiap mata kuliah. Berdasarkan sejarahnya biologi merupakan salah satu ilmu pengetahuan alam dirintis oleh
Aristoteles yang merupakan ilmuwan berkebangsaan Yunani yang disebut sebagai bapak perintis biologi. Biologi berasal dari kata bios dan logos yang artinya hidup dan ilmu. Jadi artinya ilmu yang mempelajari tentang organism hidup dan interaksinya dengan lingkungan (Tim Biologi Umum, Unand). Biologi merupakan ilmu yang kajianya sangat luas karena membahas seluruh makhluk hidup diseluruh permukaan bumi. Karena begitu luasnya cakupan ilmu biologi maka dari itu dibentuklah cabang-cabang biologi agar memudahkan untuk dipelajari. Dimana masingmasing cabang-cabang biologi tersebut memiliki cirri-ciri khas untuk dikembang sebagai peluang usaha bagi mahasiswa biologi maupun pendidikan biologi.

Cabang biologi yang membahas tentang tumbuhan adalah botani. Salah satu peluang usaha yang dapat dikembangkan dibidang botani adalah kreasi tanaman hias. Mahasiswa yang kreatif dapat melakukan ujicoba atau penelitian dengan dasar pemahaman ilmu gentika dapat menggabungkan tanaman hias satu dengan yang lainya untuk mendapatkan tanaman hias yang bernilai seni bagi penikmatnya. Selain itu, tanaman juga bisa dibentuk sesuai dengan kemampuan kreatorkreator menjadi nilai seni yang indah. Dalam hal ini, disampaing mahasiswa dapat melakukan penelitian dan pengamatan dengan harapan menhasilkan varietas atau spesies baru juga dapat membentuk karya seni yang bernilai ekonomis.

Cabang biologi yang membahas tentang mikroba adalah mikrobiologi. Beberapa jenis mikroba bermanfaat bagi keberlangsungan hidup manusia. Bakteri Acetobacter xylinum dapat mengubah limbah air kelapa yang terbuang sia-sia di pasar menjadi produk yang bernilai bagi manusia yaitu nata de coco. Acetobacter xylinum dapat membentuk serat nata jika ditempatkanatau dikembangkan dalam air kelapa yang kaya akan karbon dan nitrogen melalui proses terkontrol. Acetobacter xylinum menghasilkan enzim yang dapat menyusun gula menjadi ribuan rantai serat atau selulosa.

Cabang biologi yang membahas tentang jamur adalah fungi. Beberapa jenis fungi yang dapat dibiakan dan bernilai ekonomis adalah jamur tiram (Pleurotus ostreatus). Jamur tiram (Pleurotus ostreatus) dengan cara terkontrol dapat dibiakan dan juga sebagai sumber protein yang guna mencukupi kebutuhan nutrisi bagi manusia. Dan 
JURNAL BIOLOKUS Vol.1 (2)

masih banyak jenis-jenis jamur yang dapat dikembangbiakan dan mengandung protein juga bernilai ekonomis.

Selain itu masih banyak cabang-cabang biologi lainya yang dapat dikembang oleh mahasiswa biologi dan pendidikan biologi yang dapat bernilai ekonomis. Hal tersebut bisa berawal dari tugas kuliah ataupun tugas akhir (penelitian akhir) mahasiswa. Untuk itu mahasiswa dituntut untuk keseriusan dalam kegiatan yang daoat menghasilkan karya yang kreatif dan inovatif sesuai dengan kebutuhan dan perkembangan zaman.

\section{SIMPULAN}

Masalah pengangguran di Indonesia merupakan masalah yang serius harus di tangani secara cepat dan tepat. Tingkat pengangguran tersebut sebagian besar berasal dari mereka yang berpendidikan sarjana. Untuk itu, perguruan tinggi memiliki peran strategis untuk menanggulangi masalah tersebut. Salah satunya adalah merubah pola pikir mahasiswa setelah menjadi sarjana dari pencari kerja (job seeker) menjadi menciptakan lapangan kerja (job creator). Maka perlunya membekali mahasiswa secara teoritis tentang peluang usaha yang dapat dikembangkan berdasarkan potensi lokal maupun nasional. Sebagai mahasiswa generasi muda harus berani melangkah mengambil keputusan terhadap persaingan global. Persaingan akan mendorong menjadi pengusaha yang lebih kreatif dan inovatif dalam mengembangkan usaha.

\section{REFERENSI}

Anonimous. Jurnal Kewirausaan. Sebuah Kajian Pengabdian Kepada Masyarakat. Diakses tanggal 29 September 2018.

Dewi, Mutia. 2016. Pembelajaran Berbasis Bioentrepreneurship. UMP. Purwokerto.

Harjono, Bambang. 2012. Bahan Ajar Kewirausahawan. STT INTI.

Hatani, LA. 2008. Kewirausahaan. Universitas Haluoleo. Kendari.

https://medium.com/@TERRAITB/pentingnyaentrepreneurship-706519047a9e. diakses tanggal 29 September 2018.
Purwanto. 2006. Pengantar Kewirausahaan. UNY. Yogyakarta.

Rukka, Rusli Muhammad. 2011. Kewirausahaan. Lembaga Kajian dan pengembangan Pendidikan UNHAS. Makasar.

Sagoro, Endra Murti, 2013. Kewirausahaan. UNY. Yogyakarta.

Tim Biologi. 2011. Bahan Ajar Biologi Umum. UNAND. Padang. 